\title{
Clinical and Laboratory Evaluation of Blunt Trauma Patients for the Early Diagnosis of Intra-Abdominal Injuries
}

\author{
Yasmine Karam Zaki ${ }^{1}$, Sanaa Ibrahim Ahmed Bilal ${ }^{1}$, Mohammed Mohammed Matar ${ }^{2}$, Dalia Mohammed Nabil \\ Zaki $^{1}$ \\ ${ }^{1}$ Department of Forensic Medicine and Clinical Toxicology, Faculty of Medicine-Ain Shams University, Cairo Egypt. \\ ${ }^{2}$ Emergency Department Ain Shams University Hospitals, Cairo Egypt.
}

All rights reserved

\begin{abstract}
Background: Blunt abdominal trauma is seen with increasing frequency in emergency rooms and is continuous to be associated with significant morbidity and mortality. Intra-abdominal injuries following blunt trauma are of great medico-legal importance to forensic experts. Aim: The study aimed to investigate the contribution of non-invasively and rapidly obtained clinical presentation and biochemical parameters in the early diagnosis of intra- abdominal (IA) injuries in blunt trauma patients, then develop a scoring system and investigate its clinical applicability as pre-test to determine whether abdominal CT should be performed during the diagnosis or not. This may help to decrease number of malpractice claims due to medical negligence. Methods and results: A prospective study was conducted on 30 adult patients with blunt abdominal trauma presented to Emergency department (ED) of Ain shams university hospitals (ASUHS). Patients were classified into two groups: group 1: adult patients with blunt abdominal trauma with normal CT abdomen. Group 2: adult patients with blunt abdominal trauma with abnormal CT abdomen. For every patient, demographic, trauma, and clinical data were collected. Laboratory parameters measured included blood hemoglobin level, liver enzymes, kidney function tests, pancreatic enzymes and finally CT abdomen was done. The mean age for the adult patients with blunt abdominal trauma was $34 \pm 11$ years. Male to female ratio was 2:1 with no significant importance. There was no significant difference between both groups of the study as regards aetiology and delay time of trauma and the most common cause of BAT was motor car accidents that compromised $(36.7 \%)$ of all patients. There was no significant difference between both groups of study as regards abdominal symptoms and signs. Regarding vital signs, incidence of patients with high pulse rate per minute more than $100 \mathrm{bpm}$ and high respiratory rate more than 20 brpm were highly significant in group II than group I. There was no significant difference between both groups regarding blood pressure. As regards the conscious level, there was significant difference between both groups of study. Hemoglobin level was significantly lower group II than group I with cutoff point level equal to or less than $9.8 \mathrm{gm} / \mathrm{dl}$. AST, ALT, urea, creatinine, amylase and lipase levels showed no significant difference between both groups. According to CT, the spleen was the most injured organ in blunt abdominal trauma patients $(43.8 \%)$ followed by the liver 4 cases $(25 \%)$. Conclusion: A scoring system could be done by the sum of points obtained from each parameter ( $\mathrm{Hb}$ level, pulse rate, respiratory rate, and conscious level). The score points range from (0-4). It was found that the patients with score (0-2) were mainly with normal CT abdomen. On the other hand, patients with score (1-4) were mainly with positive CT findings. So, this scoring system can be used for the early prediction of the presence of IAIs in BAT patients and as a pretest for the need of CT. Recommendations: Blood hemoglobin level, pulse rate, respiratory rate and conscious level can be used as early predictors of IAIs in BAT patients. A scoring system using blood hemoglobin, pulse rate, respiratory rate and conscious level can be used as a pretest probability to determine the need for abdominal CT for the detection of intra-abdominal injury.
\end{abstract}

Key words Clinical and Laboratory Evaluation, Blunt Trauma Patients, Intra-Abdominal Injuries

\section{Introduction}

B lunt abdominal trauma (BAT)is seen with increasing frequency in emergency rooms and is associated with significant morbidity and mortality (Davis et al., 2005).

Intra-abdominal injuries following blunt trauma present a great medico-legal importance to forensic experts and death due to IA hemorrhage in absence of external injury. Exact injury may not be diagnosed except in operation by the surgeon or during autopsy by the autopsy surgeon (Singh et al., 2012).

Undetected intra-abdominal injuries can lead to late-stage mortality and morbidity and the treating 
surgeon may be a subject of medical negligence. So, diagnosing IAIs accurately and in a timely manner is crucial especially in blunt trauma patients (Meisler, 2011).

The spleen and liver are the most commonly injured solid organs in BAT. Injuries to the pancreas, bowel and mesentery, bladder, and diaphragm as well as retroperitoneal structures (kidneys, abdominal aorta) are less common but also be considered (Isenhour and Marx, 2007).

The accurate and timely diagnosis of blunt intra-abdominal injury is a common dilemma; the accuracy of physical examination has been questioned by multiple previous studies, while others have suggested that optimal method of diagnosis is via serial examination by an experienced trauma surgeon. Clinical examination alone is inadequate because patients may have altered mental status and distracting injuries (Hoff et al., 2002).

Although haemoglobin and haematocrit measurements alone are not sufficiently predictive in detecting intra-abdominal injuries yet must be kept in mind that low haemoglobin values should be recognized as a significant marker in assessing need for further examination to detect intra-abdominal injury (Dunk et al., 2010).

Computerized tomography (CT) is the imaging method of choice in the evaluation of abdominal and pelvic injuries after blunt trauma in hemodynamically stable patient (Miele et al., 2016).

Significant correlation was found between systolic blood pressure (SBP), pulse rate, shock index, Glasgow coma scale (GCS), abdominal examination, ultrasonography, hemoglobin level, serum creatinine kinase (Ck), serum myoglobin, amylase, lipase levels and the presence of intra-abdominal injury in BAT patients and ROC curve was performed to determine the diagnostic value of the score that was calculated to detect intra-abdominal injury with cut off value 14 with $(83.78 \%)$ sensitivity and (86.36\%) specificity (Musalar et al., 2017).

\section{Aim of the Study}

This study aimed to:

$1^{\text {st }}$ : Investigate the contribution of non-invasively and rapidly obtained clinical presentation and biochemical parameters in the early diagnosis of intra- abdominal injuries in blunt trauma patients.

$2^{\text {nd }}$ : Develop a scoring system and investigate its clinical applicability as pre-test to determine whether abdominal CT should be performed during the diagnosis or not. This may help to decrease number of malpractices claims due to medical negligence.

\section{Patients and Methods}

A prospective study was conducted on 30 adult patients with blunt abdominal trauma presented to Emergency department (ED) of Ain Shams University Hospitals (ASUHS). Patients who were enrolled in the study were classified into two groups:

Group 1: Blunt abdominal trauma patients with normal CT abdomen (without intra-abdominal injury).
Group 2: Blunt abdominal trauma patients with abnormal CT abdomen (with intra-abdominal injury).

Exclusion criteria: The following patients were excluded: patients below 18 years old, patients with pre-existing medical disease (as liver, kidney, or pancreatic disease), patients on anticoagulant therapy or blood disease and patients with penetrating abdominal trauma.

Ethical Considerations: After approval of Faculty of Medicine, Ain Shams University Research Ethics Committee and Approval of Emergency Department, a written informed consent was obtained from all patients.

For every patient in the following data were collected

1. Demographic data: age, gender.

2. Trauma data: aetiology, delay time.

3. Clinical data:

- Vital signs: arterial blood pressure, pulse, respiratory rate, and conscious level according to GCS.

- Symptoms: abdominal pain, abdominal rigidity, vomiting, difficult breathing.

- Signs: abdominal tenderness, bruises, abdominal distention, peritoneal irritation (percussion tenderness or involuntary guarding

4. Lab parameters:

Sample collection and storage: Five milliliters of venous blood samples were collected from each patient under aseptic precautions on presentation to the Emergency Department of ASUHS by a plastic disposable syringe on admission and divided into two tubes; EDTA anticoagulant tube for hemoglobin assay and $\mathrm{Z}$ serum Clot Activator tube for other laboratory parameters. The blood was centrifuged for 10 minutes with Jouan centrifuge at rate of $5.000 \mathrm{rpm}$ and the obtained serum was kept in $1.5 \mathrm{ml}$ Eppendorf tube and then stored at $-20 \mathrm{C}$ till the time of processing without repeated freeze-Thaw cycles (Winn-Deen et al., 1989). Each sample was subjected to the following parameters:

Liver profile:

- Serum Aspartate aminotransferase (AST): was assayed by quantitative kinetic assay method using aspartate aminotransferase kit (291002, Spectrum, Obour city, Cairo, Egypt) following the manufacturer's instructions. Reference range $\leq 46 \mathrm{IU} / \mathrm{L}$ (Ramakrishnan and Sulochana, 2012).

- Serum Alanine aminotransferase (ALT): was assayed by quantitative kinetic assay method using ALT kit (292002, Spectrum, Obour city, Cairo, Egypt) following the manufacturer' instructions. Reference range: $\leq 34 \mathrm{U} / \mathrm{L}$ (female), $\leq 45 \mathrm{U} / \mathrm{L}$ (male) (Kasarala and Tillmann, 2016).

Renal function tests

- Serum urea: was assayed colorimetrically by end point assay method using urea kit (URE118100, Biomed, Badr city, Cairo, Egypt) following the manufacturer's instructions. It was quantitatively determined by using a spectrophotometer capable of measuring absorbencies at $580 \mathrm{~nm}$ for serum urea. Reference range of urea: 10-40 $\mathrm{mg} / \mathrm{dl}$ (Zawada et al., 2009). 
- Serum Creatinine: The level of serum creatinine was assayed by fixed rate assay method using creatinine kit (CRE106100, Biomed, Badr city, Cairo, Egypt), following the manufacturer's instructions. It was quantitatively determined by using a spectrophotometer capable of measuring absorbencies at $492 \mathrm{~nm}$ for serum creatinine. Reference range of Creatinine: $0.4-1.2 \mathrm{mg} / \mathrm{dl}$ (Krishnegowda et al., 2017).

Pancreatic Enzymes:

- Serum Amylase: was assayed by quantitative kinetic method using Alpha amylase kit (GALG2-CNP, 2 reagent kit, Egyptian company for biotechnology, Obour city, Cairo, Egypt), The activity of Alpha amylase is stable for a month at $-20 \mathrm{c}$. Reference range: Up to $100 \mathrm{IU} / \mathrm{L}$ (Young, 2001).

- Serum lipase: was assayed by colometric kinetic assay method using (lipase-LS colometric DGMRE kit, Egyptian company for biotechnology, Obour city, Cairo, Egypt). Reference range of serum lipase: < $60 \mathrm{IU} / \mathrm{L}$ (Moss and Handerson, 1999).

- Hemoglobin test: was assayed by using automated hematological analyzer. Reference range: 11.7 to $16.1 \mathrm{gm} / \mathrm{dl}$ and 13.2 to $17.3 \mathrm{gm} / \mathrm{dl}$ in females and males respectively (Adcock et al., 2016).

5. Computed Tomography (CT): $\mathrm{CT}$ is the first line imaging modality to look for or exclude visceral injuries if the patient's hemodynamic status can sustain. According to prompt and simple rules, scanning from lung base to symphysis pubis without any oral and intravenous contrast materials is routinely performed at a 16 -slice CT scanner. A collimation of $1.5 \mathrm{~mm}$ and a pitch of 1.188 is used with a kilovoltage of $120 \mathrm{kVp}$ and auto-modulated current. 2-mm axial sections with a gap of $1 \mathrm{~mm}$ are reconstructed at first. Axial, coronal, and sagittal reformatted images are obtained at a contiguous 5-mm section. All the images are transported to picture archive and communication system (PACS). Although intravenous contrast materials are not routinely used in our hospital, we keep a flexible protocol to be tailored according to the need of individual patient. The alternation of scanning protocol is decided by the on-duty radiologist according to the initial scanning. If necessary, a bolus of intravenous contrast materials is injected at a rate of $3-5 \mathrm{~mL} / \mathrm{sec}$ with a dose of $100 \mathrm{~mL}$ and chased by $20 \mathrm{~mL}$ of saline solution. A single-phase scanning at a delay of 60 $\mathrm{sec}$ from the beginning of injection is acquired to achieve enhancement of most solid organs. If major vascular injuries are suspected, arterial phase will be obtained using auto-trace-trigger. A delay scanning will be performed at $120-180 \mathrm{sec}$ if the urinary tract injuries are suspected. If equivocal findings of bowel injuries are detected or patients' clinical condition deteriorate and bowel injuries are suspected, oral contrast materials should be administrated at a repeat CT examination. CT angiography protocol will be used for patients with suspected vascular injuries (Gong et al., 2017).

$\underline{\text { Statistical analysis }}$

Statistical presentation and analysis of data in the present study were conducted using software program SPSS Version21. Data were described in terms of mean \pm standard deviation $( \pm$ SD) and median or frequencies (number of cases) and percentages when appropriate (Zulfiqar and Bhaskar, 2016).

\section{Results}

This study was conducted on 30 adult patients with blunt abdominal trauma presented to the Emergency department of Ain Shams University Hospitals. They were classified according to absence or presence of intra-abdominal injury as detected by $\mathrm{CT}$ into:

- Group I: adult BAT patients with normal CT abdomen (no IAI, negative group) including 14 patients $(46.7 \%)$

- Group II: adult BAT with abnormal CT abdomen (with IAI, positive group) including 16 patients $(53.3 \%)$

Mean age for the adult patients with blunt abdominal trauma was $34 \pm 11$ years range from 18 to 55 years with male predominance (male to female ratio 2:1). There was no significant difference between both groups of study as regards the age and sex (table1), as well as aetiology and delay time of trauma (table 2). Similarly, no significant difference between both groups of study was found abdominal symptoms (generalized pain, localized pain, vomiting, difficult breathing) and abdominal signs (abdominal tenderness, bruises, distension, and peritoneal irritation) as shown in table (3).

Regarding vital signs, incidence of patients with high pulse rate per minute more than 100 beat/minute high respiratory rate more than $20 \mathrm{breath} /$ minute and disturbed conscious level was significant in group II in comparison to group I. But there was no significant difference between both groups in the level of blood pressure $(\mathrm{mmHg})$ as shown in tables $(4 \& 5)$.

On measuring the $\mathrm{Hb}$ level, it was significantly lower in group II when compared with group I. While AST, ALT, Bl. Urea, Creatinine, Amylase, lipase levels showed no significant difference between the two groups table (6).

According to the CT findings of the study, the spleen was the most injured organ in the BAT patients including 7 cases $(43.8 \%)$ followed by the liver 4 cases $(25 \%)$, liver with spleen injury 2 cases $(12.5 \%)$. Pancreatic injury, urinary bladder injury and (liver, pancreas, renal injury) each of them were 1 case (6.3\%) as shown in the figure (1).

According to the Roc curve figure (2) the optimum cut off point for $\mathrm{Hb}$ was below or equal to $9.8(\mathrm{gm} / \mathrm{dl})$. The presence of positive CT abdomen in blunt abdominal trauma could be predicted with $75 \%$ sensitivity and specificity $92.86 \%$ with positive predictive value (92.3) and negative predictive value (76.5). The optimum cut of point value for pulse was more than $85 \mathrm{bpm}$. The presence of positive CT abdomen could be predicted with $81.25 \%$ sensitivity 
and $85.71 \%$ specificity with positive predictive value $(86.71 \%)$ and negative predictive value $(80 \%)$.

The optimum cut off point for respiratory rate was more than $19 \mathrm{br} / \mathrm{m}$ with $81.25 \%$ and $71.43 \%$ specificity with positive predictive value $76.5 \%$ and negative predictive value $76.9 \%$.

A statistically significant relation was found between the presence of intra-abdominal injury detected by abdominal CT and blood hemoglobin level, pulse rate, respiratory rate and conscious level within the 1st 24hours as regards in table (7).

Table (8) and figure (3) show a scoring system that can be used as a pretest probability to determine the need for abdominal $\mathrm{CT}$, which is used for the detection of abdominal injury in blunt abdominal trauma. The total score has been estimated by the sum of points obtained from each parameter $(\mathrm{Hb}$, pulse, respiratory rate and conscious level). The pretest probability score was determined for each person by adding the scores obtained from each factor. The score points range from (0 to 4$)$. It was found that patients with score (0-2) were mainly with normal CT abdomen.

On the other hand, patients with score from 1-4 were mainly with positive CT findings. According to ROC curve regarding prediction score if cut off point for prediction score more than 1 , the presence of CT positive findings could be predicted with sensitivity $81.25 \%$ and specificity $92.86 \%$ and positive predictive value (92.9) and negative predictive value (81.2). So, the sum of the highly significant parameters in a scoring system is proved to be more sensitive and specific than each parameter alone as shown in figure (4).

Table (1): Difference in mean age (years) and sex between both groups of blunt abdominal trauma patients

\begin{tabular}{|c|c|c|c|c|c|c|c|}
\hline & & \multirow{2}{*}{$\begin{array}{c}\text { Negative CT } \\
\text { (Group I) }\end{array}$} & Positive CT & Total & \multirow{3}{*}{ Test value } & \multirow{3}{*}{ P-value } & \multirow{3}{*}{ Sig. } \\
\hline & & & (Group II) & No. $=30$ & & & \\
\hline & & No. $=14$ & No. $=16$ & & & & \\
\hline \multirow{2}{*}{ Age (years) } & Mean \pm SD & $32.71 \pm 10.31$ & $35.56 \pm 13.16$ & $34.23 \pm 11.80$ & \multirow{2}{*}{$-0.653 \bullet$} & \multirow{2}{*}{0.519} & \multirow{2}{*}{ NS } \\
\hline & Range & $18-55$ & $18-55$ & $18-55$ & & & \\
\hline \multirow{2}{*}{ Sex } & Female & $5(35.7 \%)$ & $6(37.5 \%)$ & $11(36.7 \%)$ & \multirow{2}{*}{$0.010 *$} & \multirow{2}{*}{0.919} & \multirow{2}{*}{ NS } \\
\hline & Male & $9(64.3 \%)$ & $10(62.5 \%)$ & $19(63.3 \%)$ & & & \\
\hline
\end{tabular}

SD: Standard deviation, No.: number, Sig.= Significance, P-value >0.05: Non- significant (NS); P-value $\leq 0.05$ : Significant $(S)$, *: Chi-square test, $\bullet:$ Independent t-test

Table (2): Difference between both groups of blunt abdominal trauma as regards aetiology and delay time of trauma.

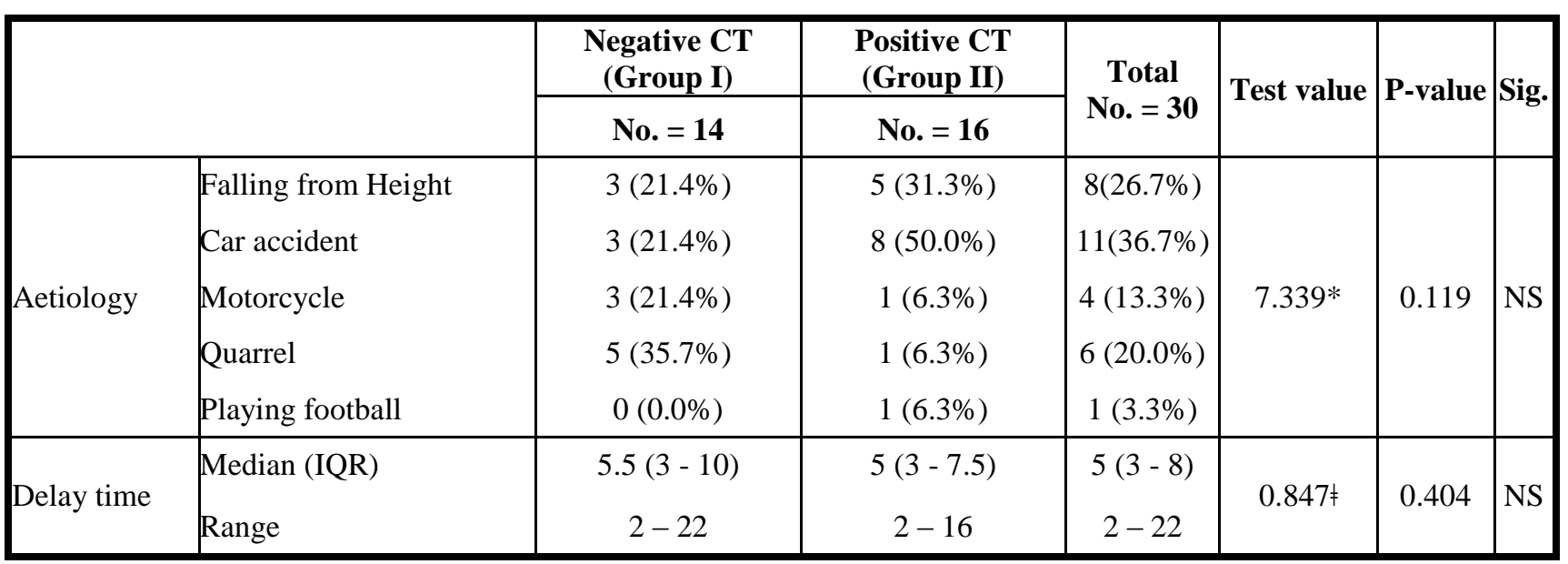

SD: Standard deviation, No.: number, IQR: Interquartile range, Sig.=Significance, P-value >0.05: Non- significant (NS); P-value $\leq$ 0.05: Significant (S); P-value <0.01: highly significant (HS), *: Chi-square test; $\neq$ : Mann Whitney test 
Table (3): Comparison between both studied groups of blunt abdominal trauma regarding symptoms and signs.

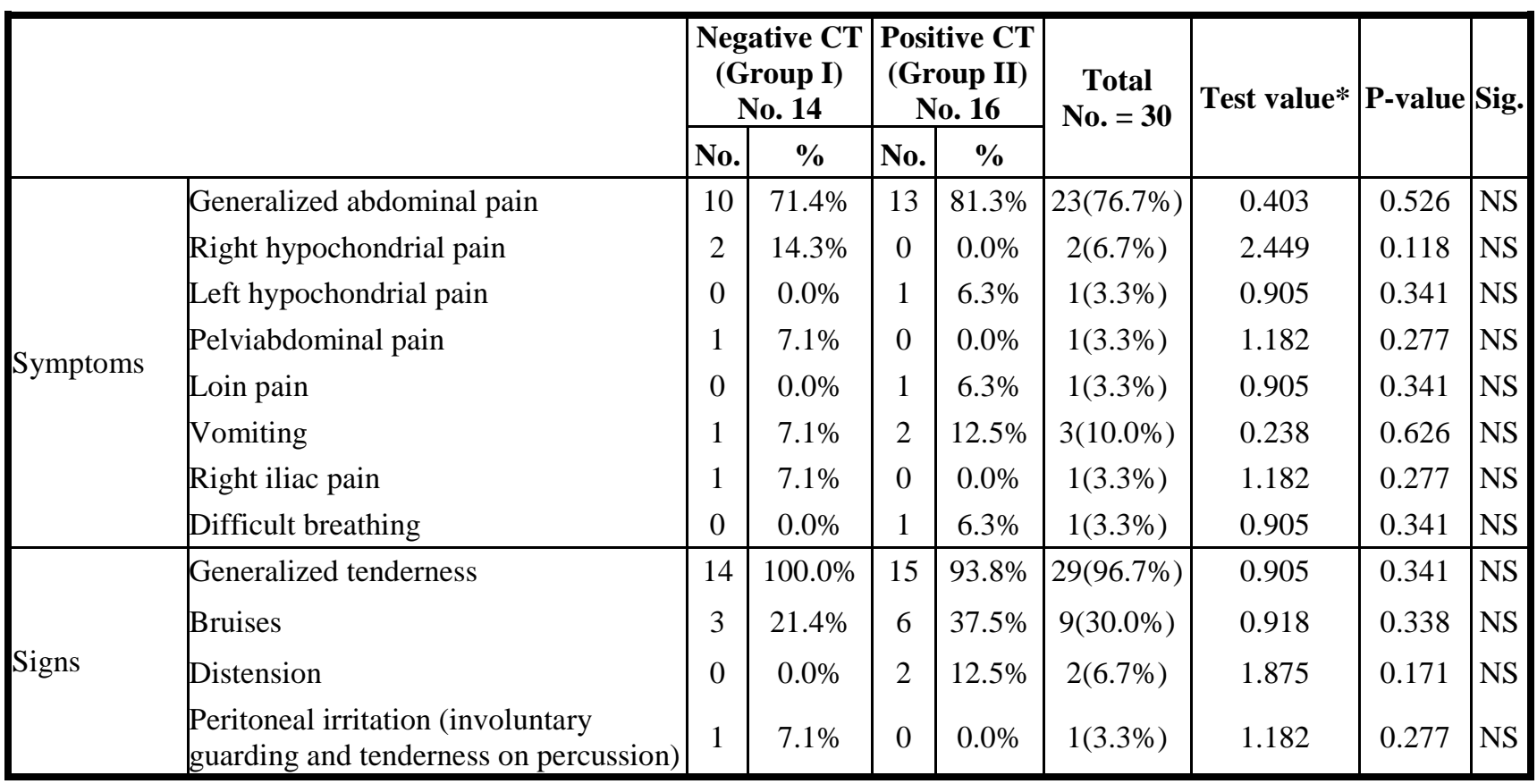

SD: Standard deviation, No.: number, Sig.= Significance, P-value >0.05: Non- significant (NS); P-value $\leq$ 0.05: Significant (S); $P$-value< 0.01: highly significant (HS), *: Chi-square test

Table (4): Comparison of means of pulse rate, arterial blood pressure and respiratory rate between both studied groups of blunt abdominal trauma.

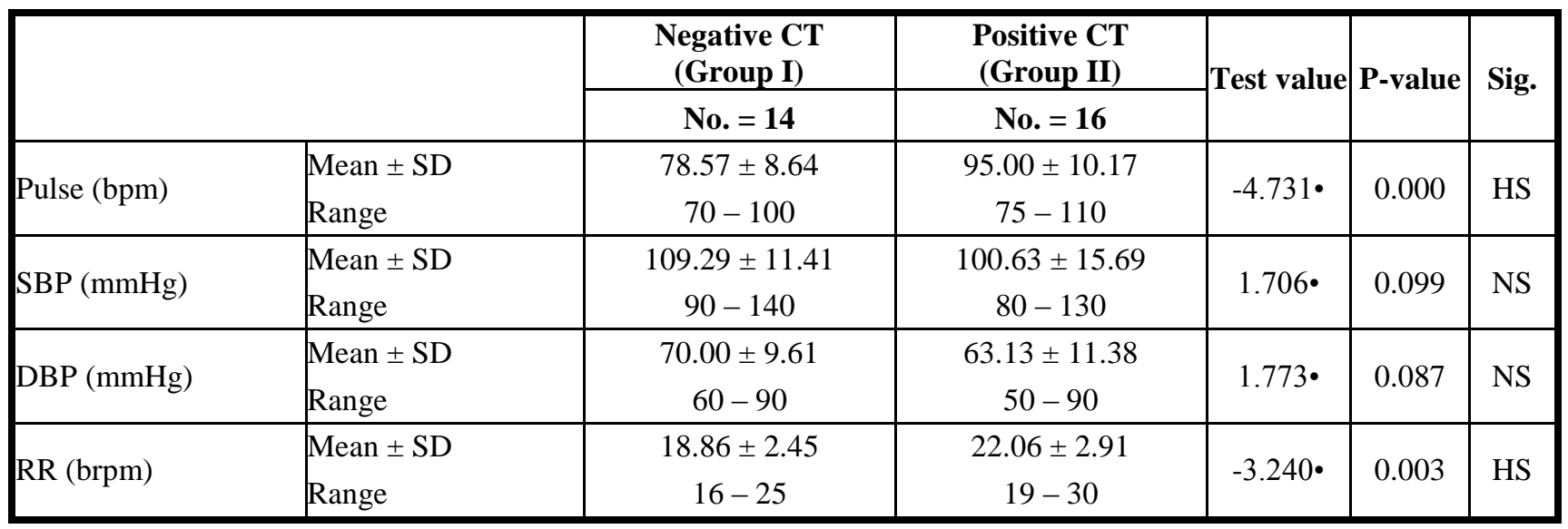

SD: Standard deviation, No.: number, Sig. = Significance, P-value >0.05: Non- significant (NS); P-value $\leq$ 0.05: Significant (S); P-value< 0.01: highly significant $(H S), \because$ Independent t-test, SBP: Systolic blood pressure; DBP: Diastolic blood pressure; RR: Respiratory rate; Bpm: beat per minute; Brpm: breath per minute.

Table (5): Comparison of conscious level between both studied groups of blunt abdominal trauma.

\begin{tabular}{|c|c|c|c|c|c|c|c|c|}
\hline \multirow[t]{2}{*}{ Conscious level } & \multicolumn{2}{|c|}{$\begin{array}{c}\text { Negative CT } \\
\text { (Group I) } \\
\text { No. 14 } \\
\end{array}$} & \multicolumn{2}{|c|}{$\begin{array}{c}\text { Positive CT } \\
\text { (Group II) } \\
\text { No. 16 } \\
\end{array}$} & \multirow[t]{2}{*}{$\begin{array}{c}\text { Total } \\
\text { No. }=\mathbf{3 0}\end{array}$} & \multirow[t]{2}{*}{$\begin{array}{c}\text { Test } \\
\text { value* }\end{array}$} & \multirow[t]{2}{*}{ P-value } & \multirow[t]{2}{*}{ Sig. } \\
\hline & No. & $\%$ & No. & $\%$ & & & & \\
\hline Conscious & 14 & $100.0 \%$ & 12 & $75.0 \%$ & $26(86.7 \%)$ & 4020 & م & $C_{1}$ \\
\hline Disturbed & 0 & $0.0 \%$ & 4 & $25.0 \%$ & $4(13.3 \%)$ & 4.038 & 0.044 & $\mathrm{~S}$ \\
\hline
\end{tabular}

SD: Standard deviation, No.: number, Sig.=Significance

$P$-value $>0.05$ : Non- significant (NS); P-value $\leq 0.05$ : Significant (S); $P$-value< 0.01: highly significant $(H S)$

*: Chi-square test 
Table (6): Comparison of means of the laboratory parameters between both studied groups of blunt abdominal trauma.

\begin{tabular}{|c|c|c|c|c|c|c|}
\hline & & Negative CT & Positive CT & \multirow{3}{*}{ Test value } & \multirow{3}{*}{ P-value } & \multirow{3}{*}{ Sig. } \\
\hline & & (Group I) & (Group II) & & & \\
\hline & & No. $=14$ & No. $=16$ & & & \\
\hline \multirow{2}{*}{ Hb (gm/dl) } & Mean \pm SD & $11.64 \pm 1.40$ & $9.35 \pm 2.25$ & \multirow{2}{*}{$3.283 \bullet$} & \multirow{2}{*}{0.003} & \multirow{2}{*}{ HS } \\
\hline & Range & $9.1-14.1$ & $5.2-16$ & & & \\
\hline \multirow{2}{*}{ AST (IU/L) } & Median (IQR) & $27.5(25-40)$ & $56.5(29-73)$ & \multirow{2}{*}{$-1.943 t$} & \multirow{2}{*}{0.062} & \multirow{2}{*}{ NS } \\
\hline & Range & $15-102$ & $18-100$ & & & \\
\hline \multirow{2}{*}{ ALT (IU/L) } & Median (IQR) & $22(15-26)$ & $30(25-50)$ & \multirow{2}{*}{$-1.620 \div$} & \multirow{2}{*}{0.117} & \multirow{2}{*}{ NS } \\
\hline & Range & $9-65$ & $20-75$ & & & \\
\hline \multirow{2}{*}{$\begin{array}{l}\text { Urea } \\
(\mathrm{mg} / \mathrm{dl})\end{array}$} & Mean \pm SD & $23.86 \pm 6.40$ & $27.27 \pm 7.06$ & \multirow{2}{*}{$-1.379 \bullet$} & \multirow{2}{*}{0.179} & \multirow{2}{*}{ NS } \\
\hline & Range & $16-35$ & $17-40$ & & & \\
\hline \multirow{2}{*}{$\begin{array}{l}\text { Creatinine } \\
\text { (mg/dl) }\end{array}$} & Mean \pm SD & $0.85 \pm 0.26$ & $0.87 \pm 0.16$ & \multirow{2}{*}{$-0.233 \bullet$} & \multirow{2}{*}{0.817} & \multirow{2}{*}{ NS } \\
\hline & Range & $0.7-1.7$ & $0.7-1.4$ & & & \\
\hline \multirow{2}{*}{$\begin{array}{l}\text { Amylase } \\
\text { (IU/L) }\end{array}$} & Mean \pm SD & $78.07 \pm 16.26$ & $88.25 \pm 26.70$ & \multirow{2}{*}{$-1.238 \bullet$} & \multirow{2}{*}{0.226} & \multirow{2}{*}{ NS } \\
\hline & Range & $60-125$ & $50-140$ & & & \\
\hline \multirow{2}{*}{$\begin{array}{l}\text { Lipase } \\
\text { (IU/L) }\end{array}$} & Mean \pm SD & $57.14 \pm 12.51$ & $57.13 \pm 29.11$ & \multirow{2}{*}{$0.002 \bullet$} & \multirow{2}{*}{0.998} & \multirow{2}{*}{ NS } \\
\hline & Range & $40-90$ & $24-100$ & & & \\
\hline
\end{tabular}

SD: Standard deviation, No.: number, IQR: Interquartile range, Sig.=Significance, $P$-value >0.05: Non-significant (NS); $P$-value $\leq 0.05$ : Significant $(S) ; P$-value $<0.01$ : highly significant $(H S), \because$ Independent $t$-test; $\neq:$ Mann Whitney test Hb: Hemoglobin, AST: Serum aspartate aminotransferase, ALT: Serum alanine aminotransferase.

Table (7): The relation between blood hemoglobin (gm/dl), pulse rate (bpm), respiratory rate (bpm), conscious level and intra-abdominal injuries in blunt abdominal trauma patients.

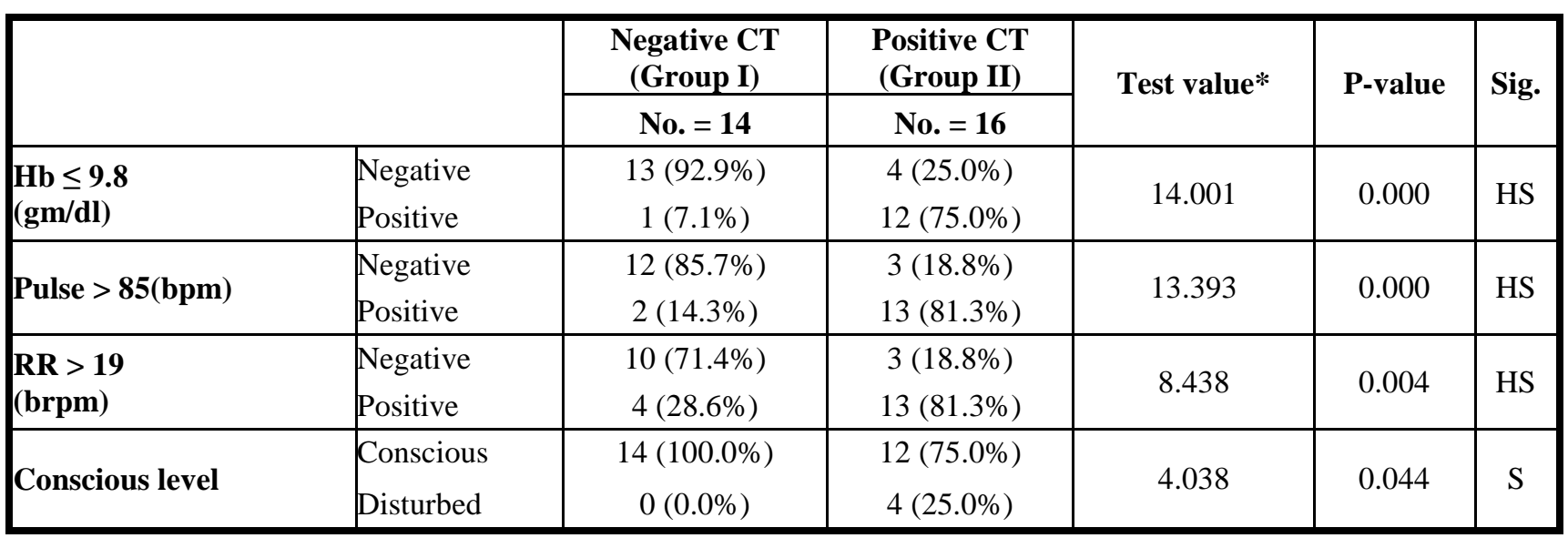

No.: number, Sig. = Significance, $P$-value >0.05: Non-significant (NS); P-value $\leq 0.05:$ Significant $(S) ; P$-value $<0.01$ : highly significant $(H S)$, *: Chi-square test, Hb: Hemoglobin, RR: Respiratory rate; Bpm: beat per minute; Brpm: breath per minute.

Table (8): A scoring system for detection of intra-abdominal injuries in blunt abdominal trauma patients.

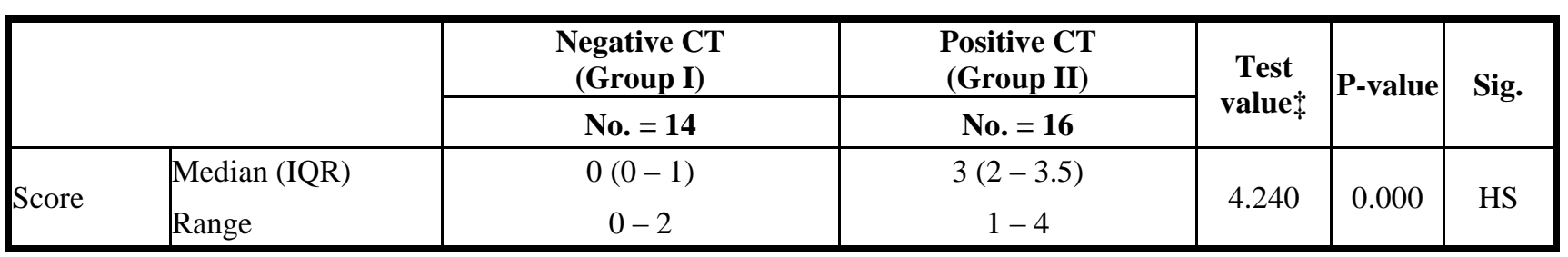

No.: number, IQR: Interquartile range; Sig.=Significance, †: Mann Whitney test, P-value >0.05: Non-significant (NS); $P$-value $\leq 0.05$ : Significant (S); P-value $<0.01$ : highly significant $(H S)$ 


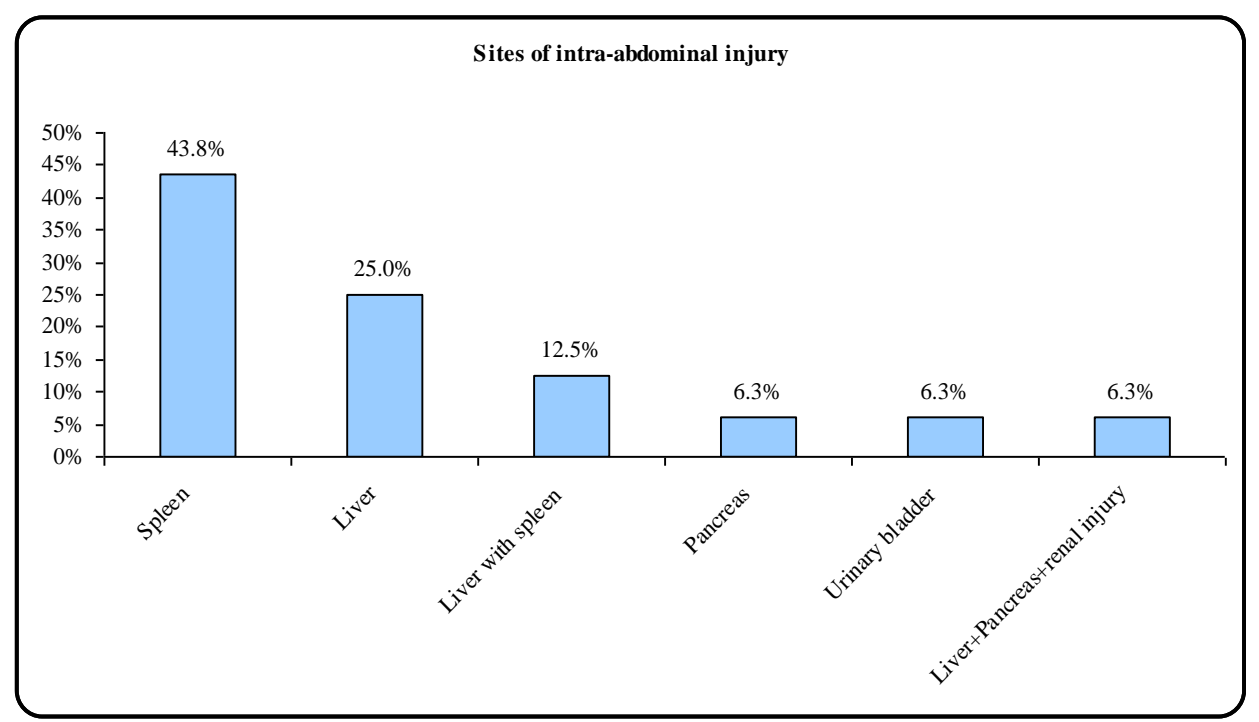

Figure (1): Column chart showing the CT findings in blunt abdominal trauma patients in group II.

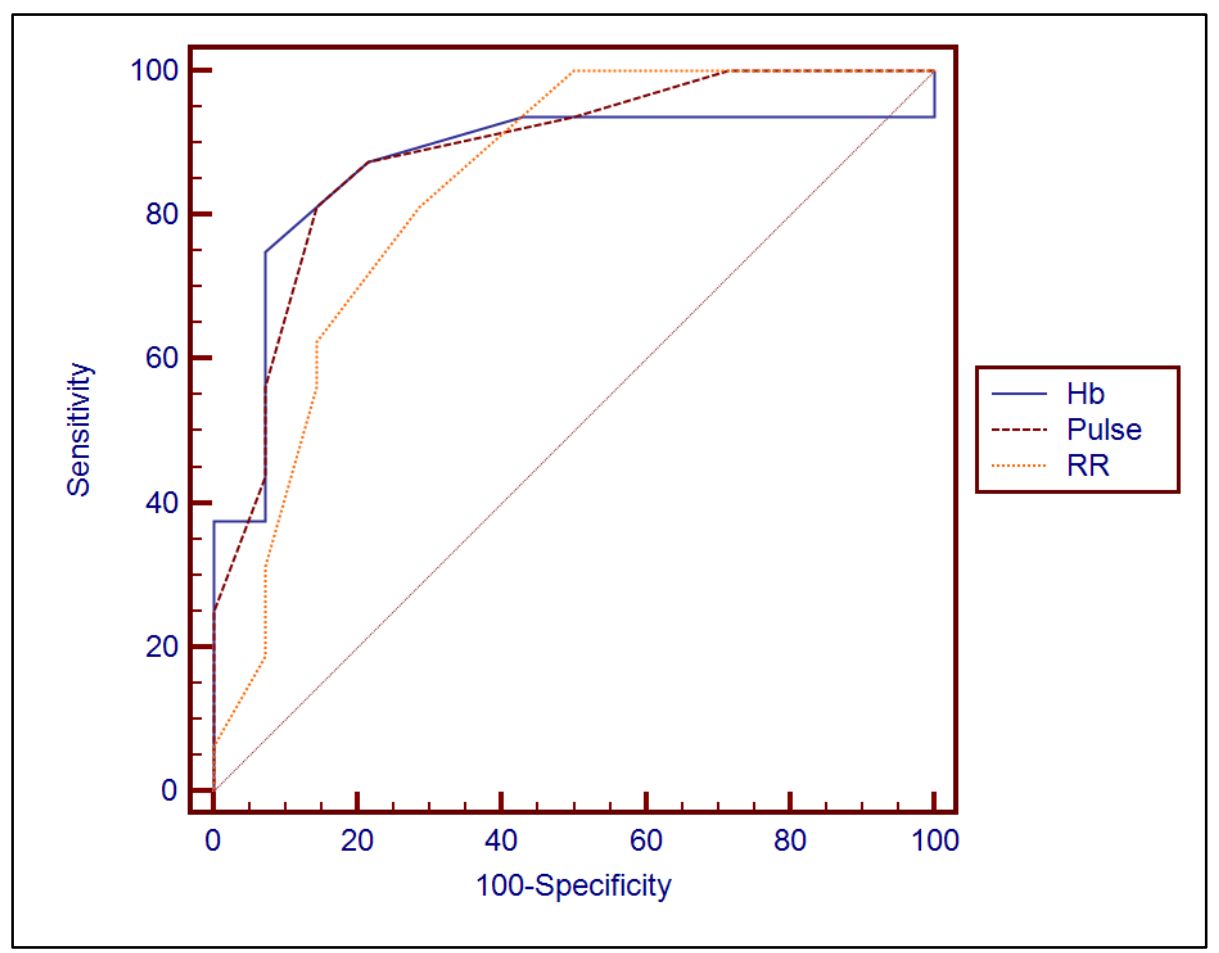

(B)

\begin{tabular}{|l|c|c|c|c|c|c|}
\hline \multicolumn{1}{|c|}{ Parameter } & AUC & Cut off Point & Sensitivity & Specificity & PPV & NPV \\
\hline Hb(gm/dl) & $\mathbf{0 . 8 7 3}$ & $\leq 9.8$ & 75.00 & 92.86 & 92.3 & 76.5 \\
\hline Pulse (beat /minute) & $\mathbf{0 . 8 8 6}$ & $>85$ & 81.25 & 85.71 & 86.7 & 80.0 \\
\hline RR (breath per minute) & $\mathbf{0 . 8 3 7}$ & $>19$ & 81.25 & $\mathbf{7 1 . 4 3}$ & $\mathbf{7 6 . 5}$ & $\mathbf{7 6 . 9}$ \\
\hline
\end{tabular}

Figure (2): A) Receiver Operating Characteristic (ROC) curve of hemoglobin level, pulse rate, and respiratory rate. B) Comparison of area under (AUC) the ROC curve, sensitivity, specificity, positive predictive value (PPV), negative predictive value (NPV) of hemoglobin level $(\mathrm{Hb})$, pulse rate, and respiratory rate (RR). 


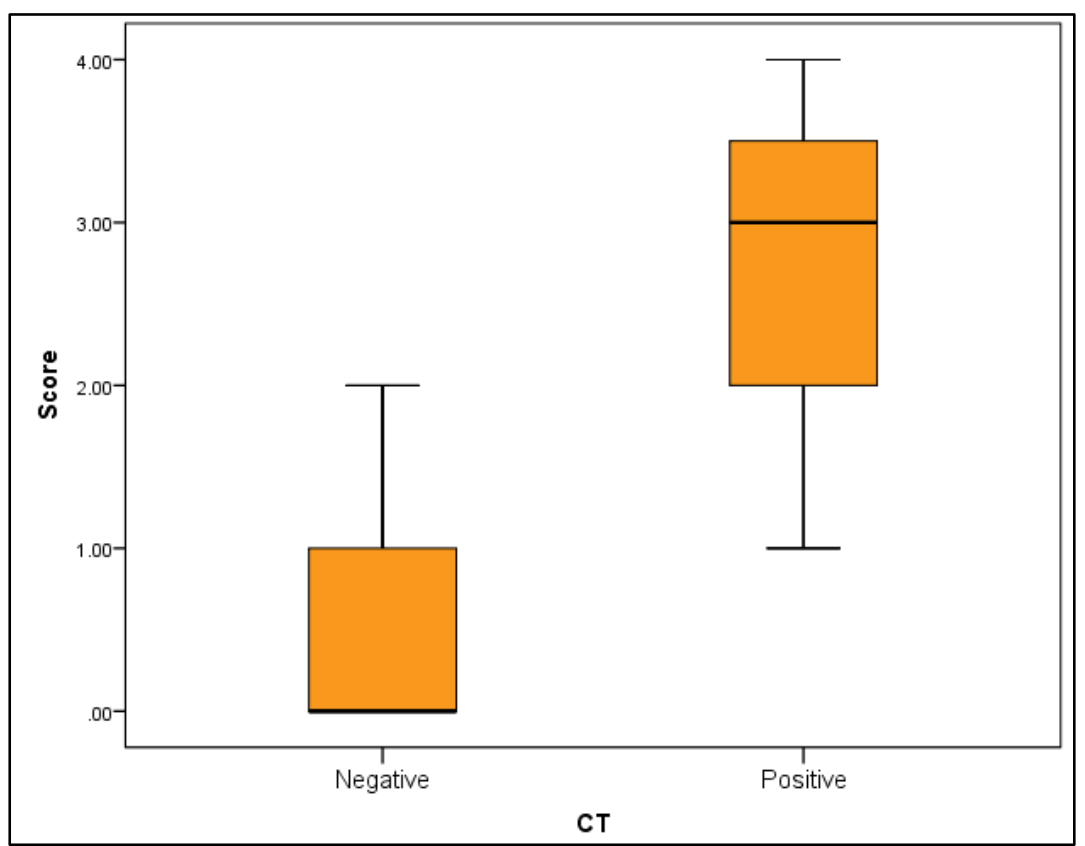

Figure (3): A scoring system of blunt abdominal trauma patients.

(A)

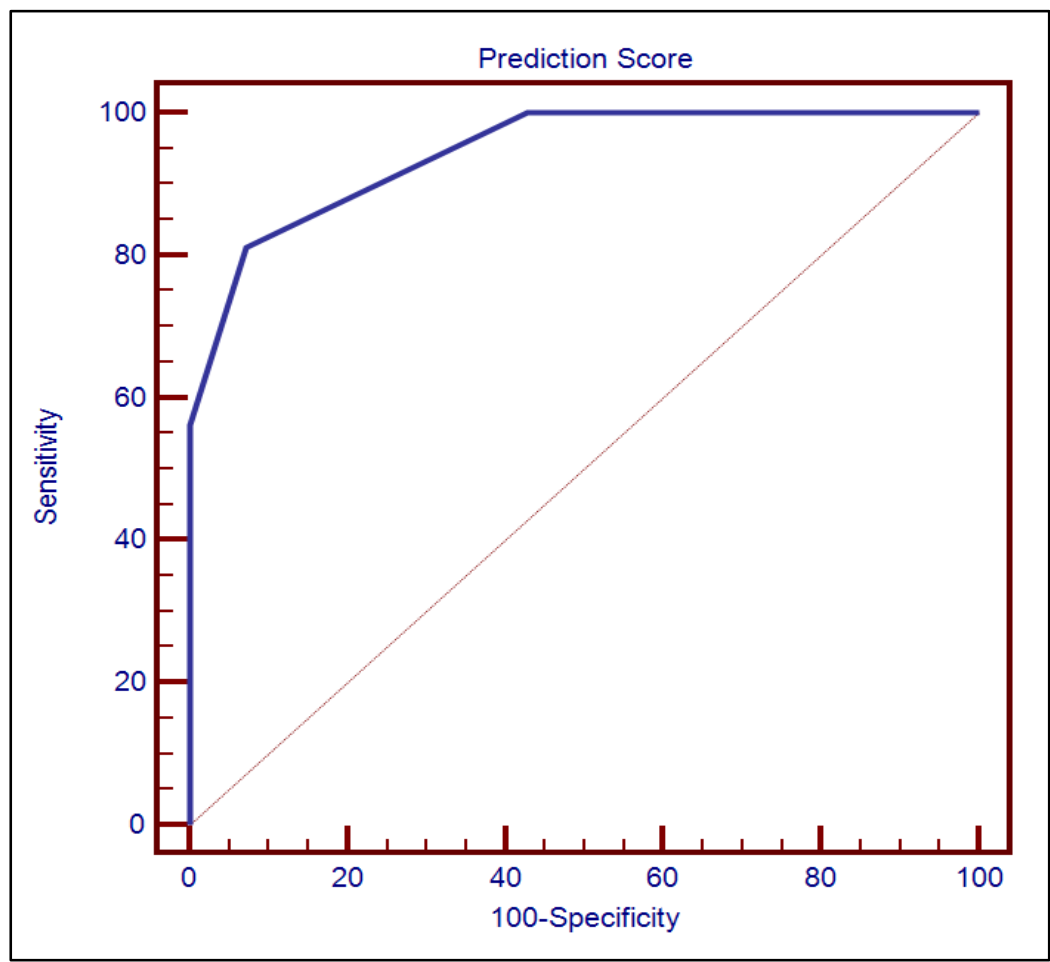

(B)

\begin{tabular}{|c|c|c|c|c|c|c|}
\hline Parameter & AUC & Cut off Point & Sensitivity & Specificity & PPV & NPV \\
\hline Prediction score & 0.944 & $>1$ & $\mathbf{8 1 . 2 5}$ & $\mathbf{9 2 . 8 6}$ & $\mathbf{9 2 . 9}$ & $\mathbf{8 1 . 2}$ \\
\hline
\end{tabular}

Figure (4): A) Receiver Operating Characteristic (ROC) curve of of the Prediction score in blunt abdominal trauma patients B) Comparison of area under (AUC) the ROC curve, sensitivity, specificity, positive predictive value (PPV), negative predictive value (NPV) of the prediction score in blunt abdominal trauma patients 


\section{Discussion}

In the current study, mean age for the adult patients with blunt abdominal trauma (BAT)was $34 \pm 11$ years with male predominance. There was no significant difference in age and gender between both groups of the study. Similar findings were noted in the study of Sahoo et al. (2017) who pointed that in cases of polytrauma blunt abdominal trauma contributes significantly to morbidity and mortality and both sexes were affected with a male preponderance. The study of Musalar et al. (2017) reported that $74 \%$ of the patients with BAT were males with a median age of 34 years. Similar percentage of male cases was also reported by Solanki et al. (2018), with a male: female ratio of 2.8:1. In the study of Abri et al. (2016), men constituted $63.9 \%$ of BTA cases and the mean age of patients was $34.15 \pm 1.6$ years. Sharma et al. (2017) reported that the most common group involved in BAT was 30-40 years followed by 20-30 years with male to female ratio $3: 1$.

On the other hand, in the study of Savatmongkorngul et al. (2017), ages of blunt abdominal trauma patients ranged from 5 to 75 years however most of cases were young age, with males constituting $84 \%$. In other study according to Srivastava et al. (2017), the majority of patients with blunt abdominal injuries were 11-20 year of age followed by 31-40 year of age group, males are predominately affected with male to female ratio was $7: 1$.

The explanation of predominance of males over females in the present study may be due to their work outside house, frequent travelling, and exposure to danger more than females. Moreover, this may be due to the fact that females in our country are less outgoing, so chances of wounding are limited (Azam, 2018). According to the current study, the most affected age to BAT is the young age, as individuals in this age group are more active in economic activities in society, and their involvement indicates a significant loss of production time in economic activities (Chalya et al., 2012).

The present study did not show significant difference between both groups of the study as regard aetiology and delay time of trauma. The most common cause of BAT was motor car accidents (36.7\%) followed by fall from height $(26.7 \%)$, quarrels $(20 \%)$, motorcycle accidents (13.3), and finally playing football $(3.3 \%)$. Similarly, the study of Isenhour and Marx (2007), reported that road traffic accidents were the most common cause of BAT in percentage of $75 \%$. According to Musalar et al. (2017), In their study outside the vehicle accidents constituted (16\%) and falls constituted $(9.2 \%)$ of the admissions to the emergency department. According to the study of Abri et al. (2016), the most common cause of blunt abdominal trauma was car crash. Also, the study of Jain et al., (2017), reported that motor car accident was the most common mode of injury. In the study of Sharma et al. (2017), the most common mode of injury was road traffic accidents (47.2\%) followed by fall from height $(27.2 \%)$ then assault $(21.8 \%)$ of cases of BAT. In the study of Srivastava et al. (2017), Out of total 48 patients with abdominal injury 24 injuries were due to road traffic accidents, 13 were due to fall from height, 7 were to assault and 2 were due to attack by animal and 2 by other mechanisms.

According to Savatmongkorngul et al. (2017), the most common mode of injury was roadside accidents $(54 \%)$ of pts followed by $(20 \%)$ of patients due to assault of different natures, $(14 \%)$ of patients due to fall from height, $(6 \%)$ due to hits from animals and $(2 \%)$ of patients due to objects falling on abdomen. Negligence of wearing seat belts, texting, drinking alcohol, and using mobile phones while driving, are among the factors that make the motor car accidents the most common cause of BAT (O'Rourke et al., 2018).

In the current study the median of the delay time from injury to presentation to ED was 3-10 hours with no significant difference between both groups of the study. This is in contrast to the study of Gosselin et al. (2009), showed that delayed injury arrival time highly contributes to the morbidity and mortality of trauma patients. Also, the study of Ntundu et al. (2019), reported that patients with a time interval $>6$ hours from injury to admission had 4 times higher odds of mortality.

The current study showed that there was no significant difference between both groups regarding their localized and generalized abdominal symptoms and signs. Abdominal pain was the most common symptom (96.6\%) of patients while abdominal tenderness was the most common sign (96.7\%) followed by bruises $(30 \%)$, abdominal distension $(6.7 \%)$ and finally peritoneal irritation $(3.3 \%)$. This agreed with Mehta et al. (2014), who found that the majority of patients with BAT presented with abdominal pain followed by vomiting, dyspnea and hematuria while among physical signs, generalized abdominal tenderness and guarding were present in $(70 \%)$ and hypovolemic shock in $(34 \%)$ of patients.

The study of Ahun et al. (2014), reported that the systolic blood pressure below $90 \mathrm{mmHg}$ prior to the hospital referral and within the emergency room or the existence of tachycardia were correlated with mortality and intra-abdominal injuries in multi-trauma patients. Another study reported that abdominal pain was the most common presenting complaint accounting for 96\% and abdominal tenderness was the most common sign accounting for $100 \%$ of cases (Srivastava et al., 2017). According to the study of Solanki et al. (2018), abdominal pain and tenderness were the most common clinical presentation (90\%) associated with blunt abdominal trauma, abdominal guarding was observed in $(46 \%)$ of cases, $(6 \%)$ patients with blunt abdominal trauma were presented with hypotension.

As regards vital signs, blood pressure has no significant difference between both groups of the study but there was significant difference in the mean values of pulse, respiratory rate, and conscious level as the majority of patients with BAT with intra-abdominal injuries had tachycardia $(25 \%)$ and high respiratory rate $(62.5 \%)$ and all cases with disturbed conscious level had positive CT abdomen.

As regard the study of Savatmongkorngul et al. (2017), the majority of patients with BAT presented 
with tachycardia (56\%) and systolic blood pressure below $90 \mathrm{mmHg}$. The increase in pulse rate, respiratory rate with normal blood pressure in patients with intraabdominal injuries in the current study can be explained by the presence of intra-abdominal hemorrhage as detected by $\mathrm{CT}$ in addition to sympathetic stimulation as a result of pain (El Menyar, 2017).

The current study showed that there was no significant difference between both groups of BAT in mean values of AST, ALT levels within the first 24hrs. The study of Sola et al. (2009), reported the usefulness of performing simple laboratory tests such as estimating the levels of serum hepatic transaminases to identify the presence of liver injury in abdominal trauma. On the contrary of the present study, Musalar et al. (2017), detected a statistically significant association between a reference serum ALT level equal to or greater than $100 \mathrm{IU} / \mathrm{L}$ and the presence of intraabdominal injury Also,the detection of serum AST level at referral equal to or greater than $80 \mathrm{IU} / \mathrm{L}$ was significantly associated with the presence of intraabdominal injury. According to Friedman et al. (2018), hepatic transaminases are useful screening hematological markers for liver injuries and should be included in the initial trauma blood test panel and may guide in the decision making especially in medical centers with limited facilities.

In the present study the mean haemoglobin level $(9.35 \pm 2.25 \mathrm{gm} / \mathrm{dl})$ was significantly lower in patients with abnormal CT abdomen (group2) in comparison to that in group1 $(11.6+-1.4 \mathrm{gm} / \mathrm{dl})$. This is mostly due to the intra-abdominal hemorrhage occurring after the blunt abdominal trauma. The study of Musalar et al. (2017), reported that it must be kept in mind that low haemoglobin values should be recognized as a significant marker in assessing the need for further examination to detect intra-abdominal injury. This is also consistent with evidence-based data stating that the presence of intra-abdominal injury in adult with blunt abdominal trauma is directly related to the level of haemoglobin in blood in the first $24 \mathrm{hrs}$ of presentation (Bouillon et al., 2018).

There was no significant difference in the median value of amylase and lipase serum levels between both groups of the current study. Also, Moretz et al. (1975), demonstrated that there was not a significant relationship between preoperative serum amylase levels and pancreatic injury with blunt abdominal trauma and the higher levels of posttraumatic serum amylase levels were not reliable for detecting or excluding any pancreatic injury. According to the study of Adamson et al. (2003), serum amylase and lipase determination may support clinical suspicion in the diagnosis of pancreatic trauma but are not reliable or cost effective as screening tools. Krige et al. (2011), reported that although serum amylase determination is the most widely used laboratory test to aid in the diagnosis of pancreatic injury, it is neither sensitive nor specific, as it may be elevated in only $80 \%$ of patients with blunt pancreatic injury. On the other hand, the study of Musalar et al. (2017), reported a statistically significant correlation between amylase and lipase levels in the study population at referral and the presence of intra-abdominal injury.

The absence of significant changes in serum liver enzymes, kidney function tests and pancreatic enzymes in the present study in contrast to other studies may be explained by some factors namely $1^{\text {st }}$ : most injuries in the current study involved the spleen $(43.8 \%)$ which does not affect these parameters, while hepatic injuries occurred in $(25 \%)$, and combined renal with pancreas and liver occurred in $(6.3 \%), 2^{\text {nd }}$ : the grades of injury might be milder compared to other studies, $3^{\text {rd }}$ : No hypotension was detected which if present may lead to pre-renal failure, $4^{\text {th }}:$ Small number of patients in this study and early sampling (delay time up to 10 hours only) might be contributing factors.

In the present study, the most common abdominal organ injured in BTA was the spleen $(43.8 \%)$ followed by the liver $(25 \%)$, liver with spleen injury $(12.5 \%)$, while pancreatic injury, urinary bladder injury and (combined liver, pancreas, renal injury) each in only one case $(6.3 \%)$. According to the study of Isenhour and Marx, (2007), the spleen and liver are the most commonly injured solid organs in BAT, and although injuries to the pancreas, bowel, mesentery, bladder, diaphragm as well as retroperitoneal structures are less common but to be considered. Similarly, in the study of Hassan et al. (2011), the spleen was the most commonly injured abdominal organ accounting for $(49 \%)$ of blunt abdominal trauma. Another study of Venkatesh et al. (2008), reported that the pancreas is rarely injured and accounts for fewer than (2\%) of all BAT injuries. Moreover, the study of Jain et al. (2017), reported that the spleen and liver are the most commonly injured solid organs as result of blunt trauma which were recorded in $49 \%$ and $21 \%$ respectively.

On the other hand, the study of Solanki et al. (2018) reported that the liver was the most common injured organ in $34 \%$ cases of blunt abdominal trauma followed by spleen (16\%). But According to Lynch et al. (2005), kidney is the third most commonly injured organ in BAT, which range from $1 \%$ to $5 \%$.

Although the spleen is protected anatomically under the rib cage in the left upper quadrant of the abdomen. It is the most common injured organ by blunt external trauma (Bjerke et al., 2017). Also, the diseased spleen (malaria, typhoid fever, leukaemia) is more susceptible to rupture than normal spleen after minor trauma (Dimaio, 2001). The kidney is the rarely damaged organ especially by frontal blunt abdominal trauma as it is deeply situated at the back of the abdomen in the paravertebral gutter (Knight, 2004).

Finally, the results of the present study showed correlation between haemoglobin level, conscious level, pulse rate and respiratory rate and the presence of intra-abdominal injury detected by abdominal CT. So, they can be used as a predictor in the early diagnosis of intra- abdominal injuries in blunt trauma patients. Then we developed a scoring system and investigated its clinical applicability as pre-test.

In the current study, the optimum cut off point for haemoglobin was equal or below $9.8 \mathrm{gm} / \mathrm{dl}$, and the 
presence of positive CT abdomen could be predicted with $(75 \%)$ sensitivity and $(92.86 \%)$ specificity with positive predictive value $(92.3 \%)$ and negative predictive value $(76.5 \%)$. As regards pulse, the optimum cut off point value was more than $85 \mathrm{bpm}$, and the presence of positive CT abdomen could be predicted with sensitivity, specificity, positive predictive value and negative predictive value of $81.25 \%, 85.71 \%, 86.71 \%$ and $80 \%$ respectively. The optimum cut off point for respiratory rate was more than 19 brpm with $(81.25 \%)$ sensitivity and $(71.43 \%)$ specificity with positive predictive value $(76.5 \%)$ and negative predictive value $(76.9 \%)$.

According to the study of Musalar et al. (2017), a statistically significant correlation was found between SBP, pulse rate, shock index, GCS, abdominal examination, ultrasonography, haemoglobin level, serum $\mathrm{Ck}$, serum myoglobin, amylase, lipase levels and the presence of intra-abdominal injury in BAT patients.

In the present study, $\mathrm{Hb}$ level, pulse rate, respiratory rate and conscious level were presented in a scoring system that can be used as pretest probability to determine the need for abdominal CT for the detection of intra-abdominal injury. The total score has been estimated by the sum of points obtained from each parameter, the pretest probability score was determined for each person by adding the scores that obtained from each factor. The score points range from (0 to 4), as each parameter was presented by 1 point. It was found that patients with score (0-2) were mainly with normal CT abdomen, on the other hand patients with score (14) were mainly with positive CT findings.

According to the study of Afifi et al. (2008), a 15 -point scoring system was designed for IAI detection in BAT patient based on five parameters including ED admission, delay time after trauma, PR, SBP, GCS and three clinical signs of abdominal trauma consisting of abdominal pain, tenderness and guarding. According to the study of Shojaee et al. (2014), a 24- point scoring system was developed obtained from each factor. The points of each factor were: abdominal pain (2), abdominal tenderness (3), chest wall sign (1), pelvic fracture (5), FAST (8), SBP less than 100mmHg (4), PR more than $100 \mathrm{~b} / \mathrm{m}$ (1). Then patients were divided into 3 groups (low risk for IAI with score below 8, high risk group with score equal or more than 12 , scores between 8-11 were identified as moderate risk patients and needed additional observations and tests to find correct diagnosis.

In the present study, ROC curve (CT group) was done to find the prediction score if cut off point for prediction score more than 1 , The presence of CT positive findings with sensitivity $(81.25 \%)$ and sensitivity (92.86\%) and positive predictive value (92.9 $\%)$ and negative predictive value $(81.2 \%)$, so the sum of the highly significant parameters in a scoring system is highly sensitive than each parameter alone. According to Musalar et al. (2017), ROC curve analysis was performed to determine the diagnostic value of the score that was calculated to detect intraabdominal injury with cut off value 14 with $(83.78 \%)$ sensitivity and $(86.36 \%)$ specificity.

\section{Conclusion}

A scoring system could be done by the sum of points obtained from each parameter ( $\mathrm{Hb}$ level, pulse rate, respiratory rate, and conscious level). The score points range from (0-4). It was found that the patients with score (0-2) were mainly with normal CT abdomen. On the other hand, patients with score (1-4) were mainly with positive CT findings. So, this scoring system can be used for the early prediction of the presence of IAIs in BAT patients and as a pretest for the need of CT.

\section{Recommendations}

Blood hemoglobin level, pulse rate, respiratory rate and conscious level can be used as early predictors of IAIs in BAT patients. A scoring system using blood hemoglobin, pulse rate, respiratory rate and conscious level can be used as a pretest probability to determine the need for abdominal CT for the detection of intraabdominal injury, especially when $\mathrm{CT}$ is not available or cannot be used.

According to this scoring system patients with score (0-2) are mainly with normal CT abdomen and they are recommended to be put under observation to prevent any delayed injury, while patients with score (1-4) are mainly with positive CT findings that needs further investigations and/or urgent management.

Surgeons should not rely on symptoms and local abdominal signs for the early diagnosis of IAIs in BAT patients. Also, liver enzymes, pancreatic enzymes, blood urea and serum creatinine are not early predictors. A special attention should be paid to spleen, liver in BAT as they prove to be the most injured organs. Moreover, intra-abdominal hemorrhage should be well controlled in BAT.

Every effort should be done to control traffic accidents being the most common cause of BAT. Other studies are recommended with larger number of patients with BAT. Try other parameters as haematocrit value, urine analysis for the early diagnoses of IAIs in BAT.

\section{References}

Abri B, Shams-Vahdati S, Paknezhad S, et al., (2016): Blunt abdominal trauma and organ damage and its prognosis. J Anal Res Clin Med; 4(4):22832.

Adamson WT, Hebra A, Thomas PB, et al., (2003): Serum amylase and lipase alone are not costeffective screening methods for pediatric pancreatic trauma. Journal of pediatric surgery; 38(3):354-7.

Adcock DM, Favaloro EJ, and Lippi G (2016): Critical pre-examination variables in the hemostasis laboratory and their quality indicators. Clinical biochemistry; 49(18):1315-20.

Afifi RY (2008): Blunt abdominal trauma back to clinical judgement in the era of modern technology. International Journal of surgery; 6(2): 91-95.

Ahun E, Köksal Ö, Sığırlı D, et al., (2014): Value of the Glasgow Coma Scale, age, and arterial blood pressure (GAP) score for predicting the mortality of major trauma patients presenting to 
the emergency department. Turkish Journal of Trauma and Emergency Surgery ;20(4):241-7.

Azam AM, Talukder MT, and Sarder MM (2018): Outcome and management strategy of traumatic liver injury in a tertiary hospital in Bangladesh. Journal of Surgical Sciences; 22(1).

Bjerke A, Kapaki E, Boban M, et al., (2017): Biochemical markers in vascular cognitive impairment associated with subcortical small vessel disease-A consensus report. BMC neurology; 17(1):102.

Bouillon RK, Nguyen MH, Chen L., et al., (2018): Pneumonia and renal replacement therapy are risk factors for ceftazidime-avibactam treatment failures and resistance among patients with carbapenem-resistant Enterobacteriaceae infections. Antimicrobial agents and chemotherapy; 62(5): e02497-17.

Chalya PL, Mabula JB, Giiti G., et al., (2012): Splenic injuries at Bugando Medical Centre in northwestern Tanzania: a tertiary hospital experience. BMC Research notes ;5(1):59.

Davis PJ, Koottayi S, Taylor A, et al., (2005): Comparison of indirect methods of measuring intra-abdominal pressure in children. Intensive care medicine; 31(3):471-5.

Dimaio VJ, Dimaio D, and Geberth VE (2001):Blunt trauma wounds. Forensic Pathology. 2nd ed. Florida, USA: CRC Press LLC:92-116.

Dunk CE, Plösch T, Gellhaus A., et al., (2010): The liver $\mathrm{X}$ receptor (LXR) and its target gene ABCA1 are regulated upon low oxygen in human trophoblast cells: a reason for alterations in preeclampsia? Placenta; 31(10):910-8.

El-Menyar A, Ahmed K, Hakim S, et al., (2017): Acute appendicitis presenting as an abdominal wall abscess: A case report. International journal of surgery case reports; 35:37-40.

Friedman SL, Ratziu V, Harrison SA., et al., (2018): A randomized, placebo-controlled trial of cenicriviroc for treatment of nonalcoholic steatohepatitis with fibrosis. Hepatology; 67(5):1754-67.

Gong Y, Amyot F, Qu B, et al., (2017): Biomarkers of Vascular Integrity in Traumatic Brain Injury and Correlation with Cerebrovascular Reactivity. Biomark J; 3:1.

Gosselin RA, Spiegel DA, Coughlin R, et al., (2009): Injuries: the neglected burden in developing countries. Bull World Health Organ; 87:246-a.

Hassan R, Aziz AA, Ralib AR, et al., (2011): Computed tomography of blunt spleen injury: a pictorial review. The Malaysian journal of medical sciences: MJMS; 18(1):60.

Hoff WS, Holevar M, Nagy KK, et al., (2002): Practice management guidelines for the evaluation of blunt abdominal trauma: The East practice management guidelines work group. Journal of Trauma and Acute Care Surgery; 53(3):602-15.

Isenhour JL, and Marx J (2007): Advances in abdominal trauma. Emergency medicine clinics of North America; 25(3):713-33.
Jain S, Maske D, and Songra M (2017): Clinical study of hollow viscus injury in abdominal trauma. International Surgery Journal ;5(1):39-44.

Kasarala G, and Tillmann HL (2016): Standard liver tests. Clinical Liver Disease; 8(1):13.

Knight JS, Mercer SJ, Somers SS, et al., (2004): Timing of urgent laparoscopic cholecystectomy does not influence conversion rate. British journal of surgery; 91(5):601-4.

Krige JE, Kotze UK, Hameed M., et al., (2011): Pancreatic injuries after blunt abdominal trauma: an analysis of 110 patients treated at a level 1 trauma centre. South African journal of surgery;49(2):58-67.

Krishnegowda S, Doreswamy SM, and Thandaveshwar D (2017): Comprehensive, noninvasive saturation, oxygen, and pressure index: Does it reflect the severity of acute respiratory illness in neonates on continuous positive airway pressure? a prospective study. Journal of Clinical Neonatology; 6(4):245.

Lynch ED, Gu R, Pierce C, et al., (2005): Combined oral delivery of ebselen and allopurinol reduces multiple cisplatin toxicities in rat breast and ovarian cancer models while enhancing antitumor activity. Anti-cancer drugs; 16(5):569-79.

Mehta N, Babu S, and Venugopal K(2014):An experience with blunt abdominal trauma: evaluation, management and outcome. Clinics and practice; 4(2).

Meisler R, Thomsen AB, Theilade P, et al., (2011): Age-related differences in mechanism, cause, and location of trauma deaths. Minerva anestesiologica; 77(6):592-7.

Miele V, Sessa B, Galluzzo M., et al., (2016): Acute perforated diverticulitis: assessment with multidetector computed tomography. In Seminars in Ultrasound, CT, and MRI; 37(1): $37-48$

Moretz JA, Campbell DP, Parker DE., et al., (1975): Significance of serum amylase level in evaluating pancreatic trauma. The American Journal of Surgery; 130(6):739-41.

Moss DW, and Henderson AR (1999): Digestive enzymes of pancreatic origin. Tietz textbook of clinical chemistry. 3rd ed. Philadelphia: WB Saunders Company; 689-98.

Musalar E, Ersel M, Akarca F et al., (2017): The predictive value of biochemical parameters in evaluating patients with abdominal trauma: The new scoring system. Turkish journal of emergency medicine; 17(2):48-55.

Ntundu SH, Herman AM, Kishe A B, et al., (2019): Patterns and outcomes of patients with abdominal trauma on operative management from northern Tanzania: a prospective single centre observational study. BMC Surgery; 19(1):69.

O'Rourke CJ, Nepal C, Oliveira DV, et al., (2018): Genomic perturbations reveal distinct regulatory networks in intrahepatic cholangiocarcinoma. Hepatology; 68(3):949-63. 
Ramakrishnan S and, Sulochana KN (2012):Manual of Medical laboratory techniques. JP Medical Ltd; 2012 Mar 29.

Sahoo NK, Singh S, Roy ID, et al., (2017): Early Postoperative Malignant Subcutaneous Emphysema: Report and Review. Journal of maxillofacial and oral surgery; 16(1):85-9.

Savatmongkorngul S, Wongwaisayawan S, and Kaewlai R (2017): Focused assessment with sonography for trauma: current perspectives. Open access emergency medicine: OAEM; 9:57.

Sharma D, Malhotra P, Gupta S, et al., (2017): Clinicoepidemiological study of blunt abdominal trauma in a tertiary care hospital in north western Himalayas. International Surgery Journal; 4(3):874-82.

Shojaee M, Dolatabadi AA, Sabzghabaei A, et al., (2014): New scoring system for intra-abdominal injury diagnosis after blunt trauma. Chinese journal of traumatology; 17(1):19-24.

Singh M, Kumar A, Verma AK., et al., (2012): Abdominal organ involvement in blunt injuries. J. Indian Acad Forensic Med. ISSN:0971-3.

Sola JE, Cheung MC, Yang R., et al., (2009): Pediatric FAST and elevated liver transaminases: an effective screening tool in blunt abdominal trauma. Journal of Surgical Research; 157(1):103-7.

Solanki HJ, and Patel HR (2018): Blunt abdomen trauma: a study of 50 cases. International Surgery Journal; 5(5):1763-9.

Srivastava SK, Jaiswal AK, and Kumar D (2017): Prospective study of management and outcome of blunt abdominal trauma (solid organs and hollow viscus injuries). International Surgery Journal; 4(10):3262-71.

Venkatesh SK, and Wan JM (2008): CT of blunt pancreatic trauma - a pictorial essay. European journal of radiology; 67(2):311-20.

Winn-Deen O, et al., (1989): Clin. Chem; 24-10.

Young DS (2001): Effects of drugs on Clinical Laboratory Tests, 4th ed, American Association for Clinical Chemistry (AACC) Press.

Zawada RJ, Kwan P, Olszewski KL, et al., (2009): Quantitative determination of urea concentrations in cell culture medium. Biochemistry and Cell Biology; 87(3):541-4.

Zulfiqar A and Bhaskar SB (2016): Basic statistical tools in research and data analysis. Indian Journal of Anaesthesia ;60(9)662-669.

\section{التقييم الإكلينيكي والمعملي في مرضى الاصابات الرضي للتشخيص المبكر لإصابات أحشاء البطن}

$$
\begin{aligned}
& \text { ياسمين كرم زكى', سناء إبراهيم أحمد بلال' , محمد محمد مطر ', داليا حممد نبيل زكى' } \\
& \text { الملخص العربى }
\end{aligned}
$$

$$
\begin{aligned}
& \text { تعتبر الاصابات الرضية بالبطن في تزايد مستمر في غرفة الطوارئ ولا تزال مرتبطة بزياده الحالات المرضيه } \\
& \text { و الوفيات تمثل الإصابات بالبطن الناتجة عن الاصابات الرضية ذات أهمية طبية قانونية كبيرة لخبراء الطب الثرعي. في بعض } \\
& \text { الأحيان قد لا يكون هناك أي إصابة خارجية ولكن المريض يتوفي من نزيف داخلي بالبطن.بعض الإصسات لا تشخص إلا اثناء } \\
& \text { العمليات الجراحية من قبل الجراح أو أثناء تشريح جثة المريض بعد وفاته. الأعضاء الداخلية بالبطن اكثرعرضة للعديد من } \\
& \text { الإصابات بسبب الجدار البطني القابل للانضغاط و الذي بنقل القوة إلى أحشاء البطن. } \\
& \text { طريقة البحث: اجري البحث علي ، م حالة من المرضي البالغون المصابون باصابات رضية التي تشمل البطن التي سيتم دخولها } \\
& \text { إلى قسم الطو ارئ في مستشفيات جامعة عين شمس خلال أول \&r ساعة من الاصابة و الذين تم اختبار هم في الدر اسة وتقسيمهم إلى } \\
& \text { مجمو عنين: }
\end{aligned}
$$$$
\text { المجمو عة الاولي: المرضى البالغين الذين يعانون من اصابات راضية ب البطن مع اشعة مقطعية سليمة )لا توجد إصابة }
$$$$
\text { داخليه بالبطن، ع ( حالة. ) }
$$

المجمو عة الثانية: المرضى البالغين الذين يعانون من اصابة راضية بالبطن مع وجود اصابه داخلية بالبطن, 17 حاله مع 
ولكل مريض تم اخذ البيانات الديموغر افية العمر والجنس، بيانات الاصابة النوع و الوقت، البيانات الاكلينكيه علامات عامة )علامات حيوية، مستوى واعي ( موضعية )ألم في البطن، تخشب بجدار البطن، وكدمات (والاختبار ات المعملية والأشعة المقطعية علي البطن لكل مريض، تم جمع البيانات الديموغر افية و البيانات الاكلينكية والاختبار ات المعملية كمستوى الهيموجلوبين

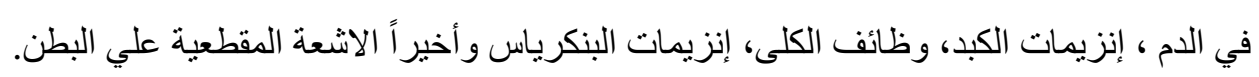

النتائج : منوسط العمر للمرضى البالغين المصابين با صابه رضيه بالبطن عب ـ 11 11 وكانت نسبه الذكور الي الاناث

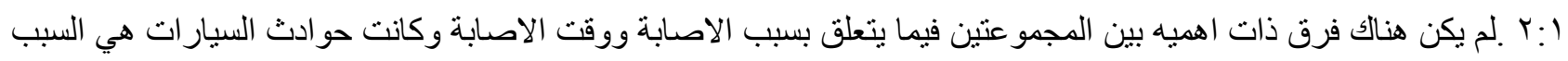

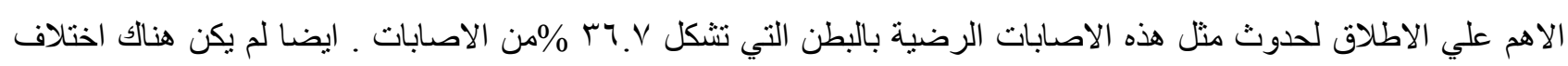

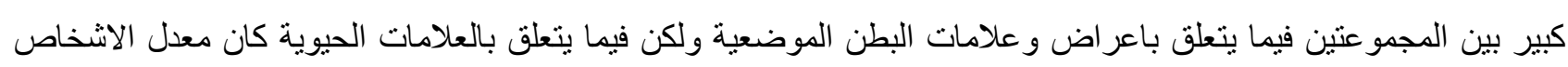

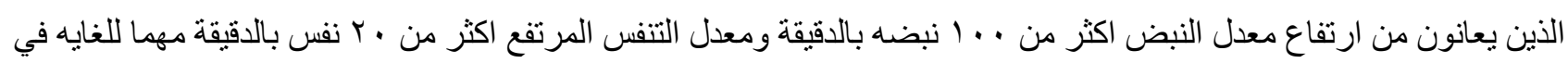

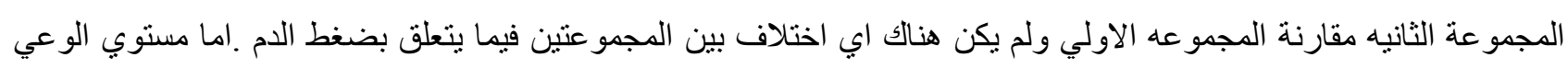
كان هنالك فرق بين المجمو عتين. وايضا مستوي الهيموجلوبين بالدم كان اقل بكثير في المجموعة الثانية مقارنه بالمجموعة الاولي

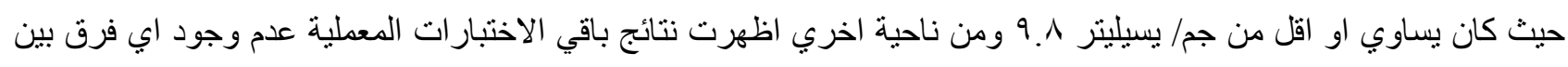
المجموعتين من حيث انزيمات الكبد ووظائف الكلي وانزيمات البنكرياس وتنين من خلال هذه الدراسة بعد استخدام الاشعة لهن المقطعية علي البطن ان الطحال هو العضو الاكثر اصابة ويليه الكبد.

الاستتتاجات: في هذه الدراسة، تم العثور على علاقة ذات دلالة إحصائية بين وجود الاصابة داخل البطن ومستوي

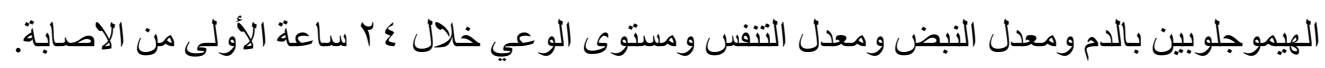

تم تقديم نتائج التحليل في مقياس معياري يمكن استخدامه كاختبار مسبق لتحديد الحاجة إلى عمل الاشعة المقطعية علي البطن، و الذي يستخدم للكثف عن الاصابة داخل البطن. 